\title{
HAVE WE FORGOTTEN K-12? THE NEED FOR PUNITIVE DAMAGES TO IMPROVE TITLE IX ENFORCEMENT
}

\author{
Katrina A. Pohlman ${ }^{*}$
}

In the fall of 2000, the Pittsburgh Tribune-Review examined 129 public high schools in southwestern Pennsylvania to evaluate the region's compliance with Title IX. ${ }^{1}$ The Tribune-Review promptly published the results, which were bleak. During the 1999-2000 academic year, two out of every three athletes were boys. ${ }^{2}$ Moreover, sixty-nine cents out of every dollar spent on school athletic programs went to boys, with the average school spending $\$ 493$ on each male athlete and $\$ 350$ on each female athlete. ${ }^{3}$ The individual results of two schools were especially troubling: Duquesne High School had only nine girls playing organized sports in $1999-2000 ;{ }^{4}$ Clairton High School had only fifteen spots on just one female sports team-basketball. ${ }^{5}$ Finally, the survey noted that collegiate athletic programs had been recruiting significantly less in the region. ${ }^{6}$ As one college coach explained, even the area's rare, exceptional athlete frequently struggled in the collegiate setting, since such athletes had never had the opportunity to become accustomed to competing against the same caliber of athletes when younger. ${ }^{7}$

What was perhaps even more troubling than the study's depiction of inequality was the clear disinterest in reform. Only 49 of the 129 schools were able to name their Title IX coordinators, ${ }^{8}$ which schools are required to have

* $\quad$ Editor in Chief, University of Pittsburgh Law Review; J.D., University of Pittsburgh School of Law, 2009. The author wishes to thank Professor Deborah L. Brake of the University of Pittsburgh School of Law for her sound guidance in preparing this Note.

1. Carl Prine, Second String: Gender Inequality in High School Athletics, PITTSBURgh TribuneREVIEw, Oct. 15, 2001, available at http://www.pittsburghlive.com/x/pittsburghtrib/news/specialreports/ titleix/.

2. Carl Prine, High Schools Won't Give Their Girls a Sporting Chance, PitTsBurgh TribuneREVIEw, Oct. 15, 2001, available at http://www.pittsburghlive.com/x/pittsburghtrib/news/specialreports/ titleix/secondstring.html.

3. $I d$.

4. $I d$.

5. Id.

6. Carl Prine, WPIAL Girls Passed Over for Scholarships, PitTSBURGH TRIBUNE-Review, May 23, 2001, available at http://www.pittsburghlive.com/x/pittsburghtrib/news/specialreports/titleix/ girlspassedover.html.

7. Id.

8. Federal Law Routinely Ignored, Pittsburgh Tribune-Review, May 22, 2001, available at 
by federal law. ${ }^{9}$ Moreover, neither state nor federal authorities had yet investigated a single case of inequality between the boys' and girls' athletic programs. ${ }^{10}$ Thus, although the disparity was startling, few schools seemed to consider the inequality to be abnormal or problematic.

At its start, Title IX produced numerous opportunities for female secondary school student athletes. Prior to its enactment in 1972, only 300,000 girls played high school sports per year, representing only $7 \%$ of high school athletes nationwide. ${ }^{11}$ Although Title IX's scope far exceeds athletics - it was designed to eliminate sex discrimination in all educational programs and activities that receive federal financial assistance - its application to athletic programs became apparent by the 1980s. By 1994, over 2.12 million girls played high school sports per year. ${ }^{12}$ In short, the immediate effect of Title IX was truly monumental.

However, as the recent Pittsburgh Tribune-Review survey demonstrates, the battle for female athletic equality is far from over. The main problem lies not in the substantive provisions themselves, which do not condone the current status of public secondary school athletic programs in Western Pennsylvania, but rather in the lack of Title IX enforcement. There are two methods for such enforcement: (1) private lawsuits, and (2) investigations by the Department of Education's Office of Civil Rights. This Note argues that the availability of punitive damages in private lawsuits is an effective and necessary method to encouraging Title IX compliance. Unfortunately, thus far, virtually no courts have upheld such awards against secondary schools for Title IX violations.

Although this Note uses a Western Pennsylvanian case study as a springboard for its analysis, it does not suggest that Title IX enforcement problems are limited to that area. On the contrary, the Note assumes that Western Pennsylvania is likely representative of many school districts across the nation. In addition, the paper does not portend to suggest that enforcement problems are limited to public K-12 schools. Private and post-secondary schools, which have also had difficulty encouraging Title IX compliance, would benefit from the availability of punitive damages as well.

Part I of this Note will discuss the functions of punitive damages in civil rights cases and their application in the Title IX context. Thereafter, the Note

\footnotetext{
http://www.pittsburghlive.com/x/pittsburghtrib/news/specialreports/titleix/federallaw.html.

9. 34 C.F.R. $\S 106.8($ a) (2008).

10. See Prine, supra note 2.

11. Deborah Brake \& Elizabeth Catlin, The Path of Most Resistance: The Long Road Toward Gender Equity in Intercollegiate Athletics, 3 DUKE J. GENDER L. \& POL'y 51, 52-53 (1996).

12. Id. at 52, 57. See also 34 C.F.R. $§ 106.1$ (2008).
} 
will focus on the two obstacles to the availability of punitive damages in Title IX claims. Part II will examine whether public schools, as municipalities, should have immunity from punitive damages under the Supreme Court case City of Newport v. Fact Concerts, Inc., which provides municipalities with such immunity for $\S 1983$ claims. ${ }^{13}$ This Note will analyze Newport to identify the test adopted in that case, study district courts' subsequent application of Newport, and conclude that the test counsels against municipal immunity in Title IX claims. Part III will examine the second, and more recent, obstacle to punitive damages in Title IX litigation. In 2002, the Supreme Court held in Barnes v. Gorman that punitive damages were not available under Title VI, ${ }^{14}$ a statute that has oftentimes been analogized to Title IX. This Note will discuss the errors in Barnes and explain why Barnes should not be extended to Title IX claims. In Part IV, the Note will conclude by emphasizing the importance of improved Title IX enforcement and the role that punitive damages can play. Although the Note will implore Congress to expressly provide for the availability of punitive damages against public secondary schools in Title IX claims, the Note will underscore that congressional action is not necessary for courts to uphold such awards today.

\section{Part I: Punitive Damages, Civil Rights Cases, and the Title IX ConteXT}

The concept of punitive damages is ancient, extending as far back as the Code of Hammurabi, dated 1760 BC. ${ }^{15}$ The modern Anglo-American doctrine of punitive damages first appeared in England in $1763 .{ }^{16}$ Since then, most American courts have considered punitive damages to be an acceptable common law remedy, a trend that was affirmed by the United States Supreme Court in 1851 in Dayv. Woodworth. ${ }^{17}$ Today, there is a wide consensus among American courts that punitive damages further two distinct, legitimate goals: retribution and deterring harmful conduct. ${ }^{18}$

13. City of Newport v. Fact Concerts, Inc., 453 U.S. 247 (1981).

14. Barnes v. Gorman, 536 U.S. 181 (2002).

15. Exxon Shipping Co. v. Baker, 128 S. Ct. 2605, 2620 (2008).

16. Id. (citing Wilkes v. Wood, 98 Eng. Rep. 489, 498-99 (1763)).

17. Day v. Woodworth, 54 U.S. 363, 370-71 (1851) ("It is a well-established principle of the common law, that in actions of trespass and all actions on the case for torts, a jury may inflict what are called exemplary, punitive, or vindictive damages upon a defendant, having in view the enormity of his offence rather than the measure of compensation to the plaintiff.").

18. Exxon Shipping, 128 S. Ct. at 2621. 
In the civil rights context, retribution and deterrence remain important and powerful functions of punitive damages. Although courts have not always been receptive to this idea, punitive damages can also serve additional functions ${ }^{19}$ that become especially important in civil rights cases. ${ }^{20}$ As the Supreme Court has acknowledged, by their very nature, civil rights cases often involve incredibly vital yet non-monetary civil and constitutional rights: "Unlike most private tort litigants, a civil rights plaintiff seeks to vindicate important civil and constitutional rights that cannot be valued solely in monetary terms ... [A] successful civil rights plaintiff often secures important social benefits that are not reflected in nominal or relatively small damages awards." ${ }^{21}$ As such, punitive damages can play a uniquely useful role. First, punitive damages can educate the public about both the significance of a particular civil rights law and the societal condemnation of violations of that law. ${ }^{22}$ Second, in practice, punitive damages can help compensate the victim by filling the gaps frequently left by compensatory damage awards in cases of non-monetary harm. ${ }^{23}$ Finally, as a result of their role in education and compensation, punitive damages can serve a paramount law enforcement function by encouraging aggrieved individuals to bring vital civil rights actions. $^{24}$

Punitive damage awards are as important to Title IX lawsuits as they are to other civil rights actions. Although most courts limit punitive damages to cases with some type of deplorable conduct, such a limitation should not inhibit punitive damages in the Title IX context. As the Supreme Court recently affirmed in Exxon Shipping Co. v. Baker, punitive damages usually apply in cases of reckless conduct. Reckless conduct is by definition neither intentional nor malicious, and does not even need to be "callous" toward the risk of harming others, so long as the conduct is "unheedful" of such risk. ${ }^{25}$

19. See David G. Owen, A Punitive Damages Overview: Functions, Problems and Reform, 39 VILL. L. REv. 363, 373-74 (1994) (categorizing the additional functions as education, compensation, and law enforcement).

20. See Caprice L. Roberts, Ratios, (Ir)rationality \& Civil Rights Punitive Awards, 39 Akron L. REv. 1019, 1020 (2006). Roberts argues that the Supreme Court judicial reform of punitive damages via BMW of N. Am., Inc. v. Gore, 517 U.S. 599 (1996), and State Farm Mut. Auto. Ins. Co. v. Campbell, 538 U.S. 408 (2003), is ill-applied to civil rights cases. More specifically, Roberts expounds the irrationality of the Supreme Court's single-digit ratio test in the civil rights context.

21. City of Riverside v. Rivera, 477 U.S. 561, 574 (1986) (upholding attorney fee award that was seven times the amount of compensatory and punitive damages). See also Roberts, supra note 20, at 1021.

22. See Owen, supra note 19, at 374-75.

23. See id. at 378-79. See also Roberts, supra note 20, at 1023.

24. See Owen, supra note 19 , at 380.

25. Id. 
Schools that continue to fail to comply with Title IX fall directly into this category of conduct: they are unheedful of the risk of harm to their female athletes. Moreover, the Exxon Shipping Court noted that punitive damages might also apply, regardless of culpability, when incentives to sue are needed to prevent conduct from going un-remedied. ${ }^{26}$ Once again, this is the exact enforcement problem that hinders Title IX.

Supreme Court decisions regarding Title IX remedies add further support to the conclusion that punitive damages would be well served in the Title IX context. Although the statute did not include an express private right of action, the Supreme Court quickly held that a private right of action was implied. ${ }^{27}$ Of course, since the private right was not express, Title IX did not specifically delineate the scope of possible remedies for Title IX violations. In 1992, the Supreme Court finally addressed the issue in the landmark case Franklin v. Gwinnett County Public Schools. ${ }^{28}$ In Franklin, the Supreme Court explained that common law provides a deep-rooted presumption of the availability of "all appropriate remedies" unless Congress indicates otherwise. ${ }^{29}$ The Court held that Congress had made no effort to restrict the presumption in Title IX or in its subsequent amendments, and thus that "all appropriate remedies" were available. ${ }^{30}$ The Court did not mention exceptions for punitive or exemplary damages. Because Congress has taken no steps to regulate Title IX damages in the interim, Franklin is still good law today.

Given the vital importance of punitive damages in civil rights cases generally and Title IX lawsuits specifically, as well as the Supreme Court's lucid last words on Title IX damages in Franklin, punitive damages should be one type of "appropriate remedy" that is available under Title IX. Accordingly, the vast majority of lower courts have correctly interpreted the broad holding of Franklin as allowing such damages. ${ }^{31}$ Unfortunately, however, two other Supreme Court cases have become obstacles to lower

26. Exxon Shipping, 128 S. Ct. at 2622.

27. Cannon v. Univ. of Chi., 441 U.S. 677, 717 (1979).

28. 503 U.S. 60 (1992)

29. Id. at $66-67$.

30. Id. at $72-73$.

31. See Schultzen v. Woodbury Cent. Cmty. Sch. Dist., 187 F. Supp. 2d 1099, 1113 (N.D. Iowa 2002); Henkle v. Gregory, 150 F. Supp. 2d 1067, 1078 (D. Nev. 2001); Canty v. Old Rochester Regional School Dist., 54 F. Supp. 2d 66, 70 (D. Mass. 1999); Crawford v. Sch. Dist. of Phila., No. CIV. A. 98-1851, 1998 WL 288288, at *2 (E.D. Pa. June 3, 1998); Doe v. Oyster River Co-op. Sch. Dist., 992 F. Supp. 467, 482 (D.N.H. 1997). See also Waid v. Merrill Area Pub. Sch., 91 F.3d 857, 862 (7th Cir. 1996) (stating without discussion that both $\S 1983$ and Title IX provide punitive damages as remedies in preemption cases). 
courts' willingness to award punitive damages under Title IX and have thus needlessly hindered Title IX enforcement.

\section{PART II: NEWPORT AND Municipal IMMUNity}

The current state of the law is discouraging. Although most lower courts acknowledge that Franklin allows for punitive damages under Title IX, all but one have applied the older Supreme Court case City of Newport v. Fact Concerts, Inc. ${ }^{32}$ to avoid punitive damage awards against municipalities, including school districts, under Title IX. ${ }^{33}$ Only one court, the Northern District of Iowa in Schultzen v. Woodbury Central Community School District,${ }^{34}$ has engaged in the correct Newport analysis.

In Newport, the Supreme Court held that municipalities have immunity from punitive damages under $\S 1983 .{ }^{35}$ In coming to that determination, the Court developed a two-step test. First, the Court looked for evidence that Congress intended to disturb what the Court considered to be a well-settled common law immunity. ${ }^{36}$ Finding none, the Court turned to the second step, asking whether "considerations of public policy dictate a contrary result." 37 After analyzing the dual purposes of punitive damages - punishment and deterrence - in the context of a $\S 1983$ lawsuit, the Court found that removal of immunity was not required. First, the Court explained that the goal of punishment would not be served because innocent taxpayers, either through an increase in taxes or through a reduction of public services, would shoulder the burden, while plaintiffs, who would have already won compensatory damages, would receive a windfall. ${ }^{38}$ Next, the Court gave several reasons why the goal of deterrence would not be met. The Court explained that it was uncertain whether municipal officers would be deterred when the exemplary damages were against the municipality itself, since indemnification might not be available under local law, and since individual officers might be incapable

32. 453 U.S. 247 (1981)

33. Compare Schultzen, 187 F. Supp. 2d at 1122-25, 1128, with Landon v. Oswego Unit Sch. Dist. No. 308, 143 F. Supp. 2d 1011, 1014 (N.D. Ill. 2001); Morlock v. West Cent. Educ. Dist., 46 F. Supp. 2d 892, 924 (D. Minn. 1999); Crawford, 1998 WL 288288, at *2; Doe v. Londonderry Sch. Dist., 970 F. Supp. 64, 76 (D.N.H. 1997). But cf. Oyster River, 992 F. Supp. at 482-84 (suggesting in dicta that the Newport rule might generally apply with some rare exceptions).

34. Schultzen, 187 F. Supp. 2d 1099.

35. Newport, 453 U.S. 247.

36. Id. at 266 .

37. Id.

38. Id. at 267. 
of paying such sizeable awards anyway. ${ }^{39}$ Therefore, the Court believed that punitive damages against individuals would be a much more effective deterrent. ${ }^{40}$ Furthermore, the Court explained that corrective action would likely occur regardless of the exclusion of punitive damages, because compensatory damage awards and superior officers' concern for government integrity would be sufficient motives for reform. ${ }^{41}$ Overall, the Court held that the costs of punitive damages, when balanced against the uncertain benefits, were too high. ${ }^{42}$ The Court's concern may have been heightened by the Court's recent interpretation of $\S 1983$ as encompassing both violations of federal statutory law and constitutional law, which had the potential to create a flood of litigation and punitive damage awards. ${ }^{43}$

Since public school districts are considered municipal entities,${ }^{44}$ federal district courts have struggled with reconciling Franklin with Newport. There is no circuit court authority that district courts can look to for guidance. Of course, since Newport was a $\S 1983$ action, not a Title IX action, the Newport rule is not automatically binding in the Title IX context. Instead, the two-part Newport test should be applied to determine whether municipal immunity from punitive damages should exist in Title IX claims. Unfortunately, all but one of the district courts that have struggled with the issue have not properly applied one or both prongs of the test. Two courts briefly explained that there was no evidence that Congress intended to displace the common law immunity, without discussing the public policy analysis required in step two. ${ }^{45}$ Another court cited Newport without any explanation at all, as if Newport itself dictated the result. ${ }^{46}$ The sole court to reject Newport immunity, Canty v. Old Rochester Regional School District, ${ }^{47}$ had an equally cursory discussion. In Canty, the Massachusetts district court briefly stated that its rejection of municipal immunity was prompted by "the sweeping language of Franklin to allow 'all available remedies," as well as the "reluctance of

40. Id. at $269-70$.

41. Id. at 269 .

42. Id. at 270

43. Schultzen v. Woodbury Cent. Cmty. Sch. Dist., 187 F. Supp. 2d 1099, 1111 (N.D. Iowa 2002). See also Maine v. Thiboutot, 448 U.S. 1 (1980).

44. Canty v. Old Rochester Reg'l Sch. Dist., 54 F. Supp. 2d 66, 69 (D. Mass. 1999) (citing Jett v. Dallas Indep. Sch. Dist., 491 U.S. 701 (1989)).

45. See Morlock v. West Cent. Educ. Dist., 46 F. Supp. 2d 892, 924 (D. Minn. 1999); Doe v. Londonderry Sch. Dist., 970 F. Supp. 64, 76 (D.N.H. 1997).

46. Crawford v. Sch. Dist. of Phila., No. CIV. A. 98-1851, 1998 WL 288288, at *2 (E.D. Pa. June 3, 1998).

47. Canty, 54 F. Supp. 2d 66. 
courts in this Circuit to offer municipal immunity in similar circumstances," but offered no further supporting explanation. ${ }^{48}$ Thus, although Canty arrived at the better result, the proper analysis was still missing. Regardless of the weakness of the Canty reasoning, it is worth noting that the district court merely denied the school district's motion to dismiss the plaintiff's punitive damages claim; ${ }^{49}$ the court did not uphold an actual punitive damages award.

As of publication time, the district court for the Northern District of Iowa is the only court to properly engage Newport. In Schultzen v. Woodbury Central Community School District,${ }^{50}$ a female student athlete filed a Title IX complaint alleging that female athletes were treated more severely than male athletes for violating the school district's conduct code. ${ }^{51}$ The court examined both prongs of the Newport test in meticulous detail. ${ }^{52}$ However, the district court nonetheless disregarded much of this sound analysis and followed the trend of upholding municipal immunity. ${ }^{53}$

The first question in a proper Newport analysis is whether Congress intended to disturb the common law municipal immunity in the Title IX context. The Schultzen court quickly held that there was no evidence of Congressional intent to displace the immunity. ${ }^{54}$ However, while it is true that Congress did not expressly reject municipal immunity to punitive damages in Title IX actions, the court should not have come to its conclusion so easily because, as the Supreme Court wrote in Franklin, "Congress made no effort [in the Title IX context] . . . to alter the traditional presumption in favor of any appropriate relief for violation of a federal right." Since the Franklin Supreme Court did not mention Newport (which was decided more than a decade earlier), a more logical conclusion is that Newport did not alter the availability of appropriate remedies, including punitive damages.

Recent statutory amendments provide further evidence of congressional intent. In the Civil Rights Act of 1991, Congress expressly exempted municipalities and other governmental entities from punitive damage awards in suits brought under Title VII, Title I of the Americans with Disabilities Act,

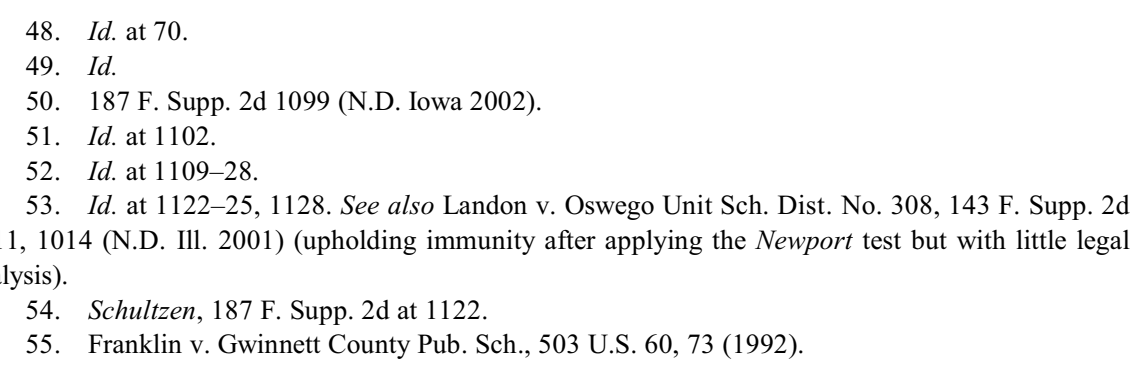


and several sections of the Rehabilitation Act, without including Title IX or Title VI (a frequent model for Title IX interpretation). ${ }^{56}$ Thus, it seems that Congress intended immunity for certain causes of action, but not for others. Moreover, since Title IX, Title VI, and $\S 504$ of the Rehabilitation Act have oftentimes been treated similarly, ${ }^{57}$ Congress's choice to include only one, not all three, in the Civil Rights Act appears to be a conscious decision, not an oversight. The fact that Congress expressly abrogated Eleventh Amendment immunity for all three statutes in the Civil Rights Remedies Equalization Act in 1986, which was enacted only five years earlier, makes the likelihood of such an oversight even more remote. ${ }^{58}$ Finally, Title IX's statutory enforcement mechanism - the possible termination of federal funds - demonstrates that Congress was not overly concerned that innocent taxpayers might have to bear the cost of public schools' noncompliance with Title IX.

The presence of common law municipal immunity in the Title IX context does not solely depend on evidence of Congressional intent. Under Newport, municipal immunity should also be rejected if "public policy dictates a contrary result" for Title IX cases. Unfortunately, the Schultzen court has been the only court to address this second prong of the Newport test. ${ }^{59}$

As discussed in Part II, supra, Newport had four main bases for its decision that public policy does not requiring waiving municipal immunity in the $\S 1983$ context: (1) waiver would not punish municipal officers, since only innocent taxpayers would shoulder the burden, (2) waiver would not deter municipal officers, since, again, only innocent taxpayers would shoulder the burden, (3) punitive damages against individuals would be a more effective deterrent, and (4) corrective action would likely occur regardless, due to compensatory damage awards and superior officers' concern for government integrity.$^{60}$ Regarding the first two rationales, there is no difference between $\S 1983$, the statute at issue in Newport, and Title IX: in both instances, the fact that punitive damages are passed onto innocent taxpayers diminishes in part the punishment and deterrence of municipal officers. ${ }^{61}$ However, there is a strong counterargument to the Newport rationale: although the officers will

56. Schultzen, 187 F. Supp. 2d at 1125.

57. See Alexander v. Choate, 469 U.S. 287, 292-99 (1985) (examining intent requirements under Title VI to interpret $\S 504$ of the Rehabilitation Act); Cannon v. Univ. of Chi., 441 U.S. 693 (1979) (examining Title VI to uphold an implied private right of action in Title IX).

58. 42 U.S.C. $\$ 2000 d-7$ (2006).

59. Schultzen, 187 F. Supp. 2d at 1122.

60. Newport v. Fact Concerts, Inc., 453 U.S. 247, 267-70 (1981).

61. Schultzen, 187 F. Supp. 2d at 1123, 1125-26. 
not themselves have to pay the punitive damage awards, they will still likely face repercussions. A punitive damage award, which indicates not just a careless act, but a wrongful act, would be highly publicized and would likely result in at least a termination of employment for those deemed responsible. The officers would probably not be able to hide behind the face of the municipality, as unhappy taxpayers would demand that someone be held accountable. Thus, in both Newport and in the Title IX context, the better argument is that the deterrent effect is intact because municipal officers would be punished if punitive damages against municipalities were allowed.

Unlike the first two rationales, the last two Newport rationales do not hold up as well in the Title IX context. First, unlike $\S 1983$ claims, punitive damage awards against individuals do not offer a more effective deterrent, as individuals are not subject to Title IX liability. The Schultzen court quickly noted the importance of the distinction: "[T]he public's interest in preventing future discriminatory conduct in educational institutions may not be capable of full realization under Title $I X$ without the imposition of punitive damages against municipal entities because individual offending officials are not, in their individual capacities, subject to Title IX liability." ${ }^{\prime 2}$ Thus, this factor clearly counsels for a different result in Title IX lawsuits.

Likewise, unlike $\S 1983$, corrective action is unlikely to occur in Title IX claims in the absence of punitive damages. First, although Title IX's statutory mechanism establishes a procedure for terminating federal funding in the event of a school's noncompliance, such a termination has never occurred in the more than thirty years since Title IX's enactment. The Schultzen court identified this distinction from $\S 1983$ as well, calling the statutory mechanism an "extreme remedy" that is "rarely imposed." 63 Second, and more importantly, unlike $\S 1983$ suits, where individuals may have lost wages, medical bills, pain and suffering damages, etc., there are virtually no cases in which compensatory damages were awarded in Title IX actions against secondary school athletic programs. There is simply no economic value on the opportunity to play sports in the public secondary school context, at least not one that is easily calculated. ${ }^{64}$ This factor, which the Schultzen court completely failed to identify, weighs even more strongly when considering that the Newport court was especially concerned with preventing plaintiff windfall - the receipt of both compensatory and punitive damages. Thus,

62. Id. at 1124 (emphasis added).

63. Id.

64. The lack of compensatory damages in Title IX cases will be discussed further in Part III, infra. 
under Newport, the removal of punitive damage awards leaves corrective action solely in the hands of superior officers concerned with government integrity. This is tantamount to having no enforcement mechanism at all. If Title IX cannot be enforced, why have it in the first place?

There is another distinction between $\S 1983$ and Title IX claims that Newport's reasoning does not expressly address. Unlike $\S 1983$ claims, which cover a wide range of behavior and are commonplace, Title IX claims, especially actions regarding unequal athletic programs, are more rare. ${ }^{65}$ Thus, the threat of a flood of litigation and punitive damage awards against public secondary schools is minimal.

Unfortunately, the Schultzen court - the only court to engage in the second prong of the Newport analysis - determined that, although "public policy arguably dictates a divergence from the traditional presumption," the court's inability to find any circuit court decisions authorizing punitive damages without express statutory authority weighed in favor of applying municipal immunity. ${ }^{66}$ This conclusion is problematic. If express statutory authority were required, the second prong of the Newport test would be irrelevant. Moreover, the requirement of express statutory authority goes against both Cannon v. University of Chicago, which created an implied private right of action, ${ }^{67}$ and Franklin v. Gwinnett County Public Schools, which did not require express language to uphold all appropriate common law remedies. ${ }^{68}$

Overall, a proper analysis of Newport in the Title IX context demonstrates that the availability of punitive damages against municipalities is not just a useful deterrent, but a necessary tool to the successful enforcement of Title IX. The cost of enforcement does not need to be high; punitive damages do not need to be pervasive and bankrupting to be effective. Juries-taxpayers and likely members of the local community-will probably not jump at the opportunity to handicap a local public school. Moreover, Title IX's statutory remedy of terminating federal funding could potentially be even more extreme. Unlike private litigation, where a jury can balance the need for punishment and deterrence against harm done to local schools and taxpayers, the termination of federal funding is an uncompromising removal of all federal

\footnotetext{
65. The numerous factors that discourage Title IX claims will be discussed at the conclusion of Part III, infra.

66. Schultzen, 187 F. Supp. $2 \mathrm{~d}$ at 1125, 1127.

67. Cannon v. Univ. of Chi., 441 U.S. 677, 717 (1979).

68. Franklin v. Gwinnett County Pub. Sch., 503 U.S. 60, 66-67 (1992).
} 
funds, on which public school budgets depend. In short, the benefits of punitive damages far outweigh the costs.

\section{Part III: Barnes And the Spending Clause}

In 2002, a second hurdle between Title IX plaintiffs and punitive damages arose. In Barnes v. Gorman, the Supreme Court held that punitive damages were not available under $\S 202$ of the Americans with Disabilities Act of 1990 (ADA) or $\S 504$ of the Rehabilitation Act of 1973 (RA) since they would not be available under Title VI. ${ }^{69}$ Although Barnes was not a Title IX case, the Fourth Circuit in Mercer v. Duke University quickly used Title VI as a proxy and applied Barnes to Title IX claims with almost no analysis:

It is well established that Title IX . . is also modeled after Title VI and is interpreted and applied in the same manner as Title VI. . . Thus, the Supreme Court's conclusion in Barnes that punitive damages are not available under Title VI compels the conclusion that punitive damages are not available for private actions brought to enforce Title IX. ${ }^{70}$

The problem is two-fold: first, Barnes itself erred in its application of the Spending Clause to Title VI; second, assuming that Barnes was decided correctly, Mercer erred in applying the same rule in the Title IX context. Unfortunately, even though the case remains unpublished, ${ }^{71}$ district courts, with no other circuit court decisions to guide them, have unanimously followed Mercer's lead. ${ }^{72}$

69. Banes v. Gorman, 536 U.S. 181 (2002).

70. Mercer v. Duke Univ., 50 F. App'x 643, 644 (4th Cir. 2002).

71. The Fourth Circuit may have used Barnes to "right the wrong it committed in its first decision interpreting the contact sports exception." Charles L. Rombeau, Barnes v. Gorman and Mercer v. Duke University: The Availability of Punitive Damages in Title IX Litigation, 6 U. PA. J. Const. L. 1192, 1205 (2004).

72. See Elizabeth S. v. Oklahoma City Public Schools, No. CIV-08-105-M, 2008 WL 4147572, at *6 (W.D. Okla. Sept. 3, 2008); James ex rel. Z.J. v. Independent School Dist., No. CIV-07-434-M, 2007 WL 3171213, at *3-4 (W.D. Okla. Oct. 25, 2007); Mansourian v. Bd. of Regents of Univ. of Cal. at Davis, No. CIV. 2-03-02591-FCD-EFB, 2007 WL 3046034, at*13 (E.D. Cal. Oct. 18, 2007); Frechel-Rodriguez v. Puerto Rico Dept. of Educ., 478 F. Supp. 2d 191, 198-99 (D.P.R. 2007); Alston v. North Carolina A \& T State Univ., 304 F. Supp. 2d 774, 784 (M.D.N.C. 2004). See also Plamp v. Mitchell School Dist. No. 17-2, No. CIV. 07-4009, 2008 WL 2277519, at*12 (D.S.D. June 3, 2008); Dawn L. v. Greater Johnstown School Dist., No. 3:2006-19, 2008 WL 857453, at*15 (W.D. Pa. Mar. 31, 2008); Doe v. Omaha Public School District, No. 8:04CV295, 2005 WL 2347284, at *6 (D. Neb. Sept. 26, 2005). Although decided post-Mercer, the latter courts based their opinions on the Newport line of cases and did not cite Barnes or Mercer. 
The Supreme Court case Barnes v. Gorman concerned an arrested paraplegic who was improperly transported to a police station and refused the opportunity to empty his urine bag, which resulted in serious medical problems, including a bladder infection, serious lower back pain, and uncontrollable spasms in his paralyzed areas ${ }^{73}$ The jury awarded the plaintiff $\$ 42,566.33$ for medical expenses, $\$ 342,251.00$ for lost past wages, $\$ 500,000.00$ for lost future wages, $\$ 150,000$ for pain and suffering, and $\$ 1.2$ million in punitive damages. ${ }^{74}$ Thereafter, the trial court found that punitive damages were not available as a matter of law and vacated that portion of the award. ${ }^{75}$ The Supreme Court affirmed. Although not a Title VI case, the Court determined that punitive damages would not available under Title VI because Title VI was enacted under the Spending Clause. ${ }^{76}$ Consequently, the Court explained, since both $\S 202$ of the ADA and $\S 504$ of the RA expressly looked to Title VI to determine the scope of available remedies, punitive damages were not available under either statute. ${ }^{77}$

The Barnes Court erred in its application of the Spending Clause to Title VI. The Supreme Court originally determined that Title VI and Title IX were enacted pursuant to the Spending Clause because Congress attached conditions to the award of federal funds in each statute. ${ }^{78}$ As a result, the statutes are interpreted as being in the nature of a contract: in return for federal funds, the entities agree to comply with federal conditions. ${ }^{79}$ The Supreme Court discussed the effect of such an interpretation in Pennhurst State School and Hospital v. Halderman:

The legitimacy of Congress' power to legislate under the spending power thus rests on whether the State voluntarily and knowingly accepts the terms of the "contract." ... There can, of course, be no knowing acceptance if a State in unaware of the

73. 536 U.S. at $183-84$

74. Gorman v. Easley, No. 95-0475-CV-W-3, 1999 WL 34808615, at*1 (W.D. Mo. Oct. 28, 1999).

75. $I d$.

76. Barnes, 536 U.S. at 188.

77. Id. at 189. Although the Civil Rights Act of 1991, discussed in Part II, supra, exempted municipalities from punitive damage awards under the ADA and RA, it did not prohibit all punitive damage awards.

78. See Barnes, 536 U.S. at 185-86 (holding that "Title VI invokes Congress's power under the Spending Clause ... to place conditions on the grant of federal funds") (emphasis added); Davis v. Monroe County Board of Education, 526 U.S. 629, 640 (1999) (nothing "we have repeatedly treated Title IX as legislation enacted pursuant to Congress' authority under the Spending Clause"); Gebser v. Lago Vista Indep. Sch. Dist., 524 U.S. 274, 287 (1998).

79. Pennhurst State Sch. and Hosp. v. Halderman, 451 U.S. 1, 17 (1981). 
conditions or is unable to ascertain what is expected of it. Accordingly, if Congress intends to impose a condition . . . it must do so unambiguously. ${ }^{80}$

Thus, Pennhurst requires that recipients have notice of any conditions attached to the award of federal funds. Although Pennhurst does not excuse recipients' ignorance of unambiguous law, it does require that the conditions imposed by Title VI and Title IX be clearly ascertainable. This rule makes logical sense; recipients should be apprised of their contractual obligations.

The Supreme Court expanded this doctrine in Gebser v. Lago Vista Independent School District, a Title IX sexual harassment case. ${ }^{81}$ In holding that "it would 'frustrate the purposes' of Title IX to permit a damages recovery against a school district for a teacher's sexual harassment of a student based on principles of respondeat superior or constructive notice," the Court explained more generally that, "[I]t does not appear that Congress contemplated unlimited recovery in damages against a funding recipient where the recipient is unaware of discrimination in its programs. ${ }^{" 82}$ In short, Gebser requires that recipients have actual knowledge of the facts at issue for damage liability to apply. Thus, in addition to having notice of the conditions, as required by Pennhurst, recipients must also have notice of the facts that give rise to the discrimination.

Unfortunately, the Supreme Court overextended the Pennhurst and Gebser doctrines in Barnes v. Gorman ${ }^{83}$ In Barnes, the Court decided that since punitive damages are not generally available for breach of contract claims, ${ }^{84}$ the Board of Police Commissioners of Kansas City (the recipient of federal funding) did not have the requisite knowledge that the officers' conduct could result in punitive damages. Thus, according to the Court, the Board could not be held liable for such damages. This result does not follow from Pennhurst's statement of the law; the Court did not determine that the recipient was "unaware of the conditions" imposed by the ADA and RA, nor that ambiguities in the law made it "unable to ascertain what [was] expected of it." ${ }^{, 85}$ Neither does the result follow from Gebser: the Court made no finding that the recipient was unaware of the officers' discriminatory conduct, or of any other facts of the case. Thus, instead of classifying the case as demonstrating either a lack of clarity in the conditions or a lack of knowledge

80. Id.

81. 524 U.S. 274 (1998)

82. Id. at 285 (emphasis added).

83. See also Rombeau, supra note 71, at 1203-04.

84. Barnes v. Gorman, 536 U.S. 181, 187 (2002).

85. Pennhurst, 451 U.S. at 17. 
of the facts, the Court improperly excused the ignorance of an unambiguous law - the common law availability of punitive damages affirmed in Franklin. ${ }^{86}$

The Court made two arguments in support of its extension of the Pennhurst-Gebser doctrine, both weak. First, the Court stated that "it is doubtful whether [the recipient] would even have accepted the funding if punitive damages liability was a required condition." 87 However, the contention that a recipient would reject funding due to the possibility of liability for wrongful conduct is extremely circumspect. Entities that receive federal funding rarely have cash to spare. On the contrary, police departments, like public schools, probably already have strained budgets.

Second, the Court warned that punitive damages, when combined with compensatory damages, "could well be disastrous." ${ }^{88}$ But the Court did not adequately explain why it was taking this determination out of the hands of the jury. Although the original total award in Barnes was extensive- - over \$2 million dollars ${ }^{89}$ - there is no reason to think that every jury would slap a recipient with excessively high punitive damage awards, especially since recipients are protected by constitutional limitations on such awards. Juries can only award punitive damages when an intent threshold, such as recklessness or malice, has been met. Juries are also asked to consider the defendant's ability to pay punitive damages, and courts have the power to reduce or vacate excessive awards. Finally, in addition to taking the decision out of the hands of the jury, the Supreme Court failed to take into account the possibility that compensatory damages might be an insufficient deterrent in particular circumstances. Interestingly, the Court's concern for excessive awards is at odds with the more extreme express statutory remedy of terminating all federal funding.

Unfortunately, until Congress legislates otherwise, Barnes is binding precedent for Title VI, the ADA, and the RA. However, it is not binding precedent for Title IX. Mercer v. Duke University erred in applying Barnes to Title IX claims, for doing so severely handicaps Title IX's enforcement mechanism, particularly regarding claims of inequality in the athletic programs in public secondary schools.

As a preliminary matter, it is undisputed that Barnes did not expressly state that punitive damages were unavailable under Title IX, and such language would have been dicta and thus circumspect regardless. More

\footnotetext{
86. Franklin v. Gwinnett County Pub. Sch., 503 U.S. 60, 66-67 (1992).

87. Barnes, 536 U.S. at 188.

88. Id.

89. Gorman v. Easley, No. 95-0475-CV-W-3, 1999 WL 34808615, at*1 (W.D. Mo. Oct. 28, 1999).
} 
importantly, although Title VI was used as a proxy for the ADA and RA, both of these statutes expressly direct courts to look to Title VI to determine the scope of available remedies. ${ }^{90}$ In contrast, there is no comparable statutory language in Title IX. Courts have construed Title VI and Title IX similarly in some situations, ${ }^{91}$ but nothing in Title IX's language expressly directs courts to copy Title VI jurisprudence without explanation. Title VI and Title IX are distinct statutes that attempt to remedy different instances of discrimination. As such, any attempt to lump the statutes together without discussion, like the court did in Mercer ${ }^{92}$ is little more than indolent judicial expediency. ${ }^{93}$ The fact that the Supreme Court determined that both Title VI and Title IX were enacted under the Spending Clause does not mean that a list of rules automatically attaches to each statute. As the Court in Barnes explained, "we have been careful not to imply that all contract-law rules apply to Spending Clause legislation." ${ }^{94}$ Thus, the best approach is to examine each statute separately to determine which contract law rules are appropriate to apply.

An examination of Title IX claims counsels strongly against borrowing the Title VI punitive damages bar. Similar to the application of municipal immunity, discussed in Part II, supra, the main problem with applying Barnes to Title IX claims is that it leaves many plaintiffs, and virtually all plaintiffs that contest unequal athletic programs, without an adequate remedy, effectively handicapping Title IX's enforcement mechanism. The problem lies in the fact that it is nearly impossible to place an economic value on playing sports. This issue is compounded in the secondary school context: although collegiate athletes can possibly cite lost scholarship money as a measure of damages, most younger secondary school athletes can only argue that they have been deprived of the potential to receive future athletic scholarships, which are incredibly speculative. Consequently, unlike Title VI plaintiffs, who might have lost wages or pain and suffering damages to recover, Title IX plaintiffs will generally not have a claim for compensatory damages.

If punitive damages are not available under Title IX, plaintiffs are left with only one reason to bring Title IX lawsuits: injunctive relief. This

90. 29 U.S.C. $\$ 794 \mathrm{a}(\mathrm{a})(2)($ section 505(a)(2) of the RA declares that the "remedies, procedures, and rights set forth in title VI . . s shall be available" for violations of $\S 504$ the RA); 42 U.S.C. $\$ 12133$ (section 203 of the ADA states that the "remedies, procedures, and rights set forth in [ $\$ 505(\mathrm{a})(2)$ of the RA] shall be the remedies, procedures, and rights" for violations of $\S 202$ of the ADA). See also Barnes, 536 U.S. at 185 .

91. See Cannon v. Univ. of Chi., 441 U.S. 677, 694-704 (1979).

92. Mercer v. Duke Univ., 50 F. App'x 643, 644 (4th Cir. 2002).

93. Rombeau, supra note 71, at 1204.

94. 536 U.S. at 186. 
effectively brings Title IX's deterrent value to zero. First, because students will likely graduate before their case is concluded, students will be disinclined to bring claims solely for injunctive relief. Second, if the only thing schools and other recipients need to fear is a court-mandated requirement to change policies, schools and other recipients have no incentive to remedy Title IX violations prior to the commencement of a lawsuit. Although Title IX also provides for a termination of federal funding, such a termination has never occurred in the history of Title IX, as recipients are first given numerous opportunities to comply with the law. ${ }^{95}$ Likewise, the plaintiff's ability to recover attorneys' fees does not change the analysis. Instead of encouraging Title IX compliance, attorneys' fees awards only encourage schools and other recipients to settle once a complaint has been filed. Moreover, the lack of a punitive damage award may diminish the plaintiff's level of success, thus affecting the plaintiff's ability to recover attorneys' fees at all. ${ }^{96}$

Although Mercer v. Duke University concerned a collegiate athlete, not a secondary school athlete, the case serves as a perfect example of this dilemma. Heather Sue Mercer, who experienced success as a field goal place kicker on her high school football team, decided to try out for the Duke University team. ${ }^{97}$ Although Title IX did not require the Duke coach to give Mercer the opportunity to try out, he did, and he eventually offered her a spot on the team. ${ }^{8}$ However, due to publicity concerns, the coach quickly began to discourage Mercer from participating. ${ }^{99} \mathrm{He}$ refused to let her attend the preseason camp. ${ }^{100} \mathrm{He}$ also suggested that she try other extracurricular

95. For criticism of Title IX's statutory mechanism, see also Alexandra A. Bodnar, Arming Students for Battle: Amending Title IX to Combat the Sexual Harassment of Students by Students in Primary and Secondary School, 5 S. Cal. Rev. L. \& Women's Stud. 549, 572 (1996) (arguing that because the withdrawal of federal funding is severe and not always appropriate with isolated violations, a "private remedy is often more practical"); Roak J. Parker, Compensatory Relief Under Title IX of the Education Amendments of 1972, 68 ED. LAw REP. 557, 561-62 (1991) (reasoning that because regulations place more emphasis on the systematic monitoring and correction of discrimination, and less emphasis on the investigation and correction of individual discrimination, Title IX has proven to be ineffective and untimely in providing remedies for individual victims of sex discrimination); Ellen J. Vargyas, Franklin v. Gwinnett County Public Schools and Its Impact on Title IX Enforcement, 19 J.C. \& U.L. 373, 381 (1993) (suggesting the administrative remedy is not a "viable alternative" because the Office of Civil Rights in the Department of Education has provided little relief to discrimination complainants).

96. See Sabrina Bosse, Is the Price of Victory Just?: Attorney's Fees, Punitive Damages, and the Future of Title IX in Mercer v. Duke University, 13 Vill. Sports \& ENT. L.J. 319 (2006).

97. Mercer v. Duke Univ., 181 F. Supp. 2d 525, 529 (M.D.N.C. 2001).

98. Id. at 529-31.

99. Id. at 531 .

100. Id. 
activities, such as beauty pageants or cheerleading. ${ }^{101}$ In time, Mercer was not only taken off of the active roster, but eventually dismissed from the team, even though she had been consistently kicking well at practice. ${ }^{102}$ The jury found that the coach had discriminated against Mercer on the basis of her gender and awarded her $\$ 1$ in compensatory damages-Mercer did not have an athletic scholarship and there was no other measure of compensatory damages - and \$2 million in punitive damages. ${ }^{103}$

Unfortunately, Mercer did not get to keep her award. On appeal, the Fourth Circuit, citing Barnes, vacated the punitive damage award. ${ }^{104}$ In addition, the district court thereafter reduced Mercer's attorneys' fees award by $20 \%$. Using twisted logic, the court explained that Mercer had not received the required "excellent results": although Mercer had established that Duke was liable for gender discrimination, Mercer had been unable to prove compensatory damages and her punitive damage award had been vacated. ${ }^{105}$ Thus, Mercer felt the blow of the vacated punitive damage award twice. After years of litigation, Mercer was left with virtually nothing.

As Mercer demonstrates, not only does the unavailability of punitive damages eliminate schools' incentive to comply with Title IX prior to litigation, it significantly reduces female athletes' interest in bringing Title IX suits in the first place. This is especially problematic in the Title IX sports context, where incentives are already low. First, unlike the average litigant, Title IX plaintiffs are under a strict time constraint - they graduate. Female athletes, especially those in their last years of secondary school, might decide that the likelihood that they would miss the benefits of injunctive relief weighs against the time and expensive of litigation. Furthermore, unless plaintiffs file class actions, which are more cumbersome and costly than individual lawsuits, plaintiffs face the risk that their claims might become moot upon graduation, making the entire ordeal for naught.

A second problem is that, unlike college athletes, who often travel to attend school, plaintiffs from secondary schools must fight an institution that is deeply ingrained in their community. As such, plaintiffs may face severe criticism not only from members of the school, but also from friends, prominent members of the community, or other community institutions. Punitive damages give wronged plaintiffs additional incentive to overcome

101. Id. at 532 .

102. $I d$. at 532,534 .

103. Id. at 535 .

104. Mercer v. Duke Univ., 50 F. App'x 643, 644 (4th Cir. 2002).

105. Mercer v. Duke Univ., 301 F. Supp. 2d 454, 468-69 (M.D.N.C. 2004). 
this adversity. In contrast, the national media attention given to verdicts like Mercer v. Duke University, in which the lack of compensatory and punitive damages prevented Heather Mercer from receiving any moral vindication that she had been treated wrongly, discourages would-be plaintiffs from enforcing their rights.

Courts should take these concerns regarding the availability of alternative remedies into account when determining whether to apply Barnes to Title IX. The Supreme Court explained in Cannon v. University of Chicago that Congress had two objectives in enacting Title IX: Congress wanted (1) to avoid the use of federal resources to support discriminatory practices, and (2) to provide individual citizens with effective protection against those practices. ${ }^{106}$ In creating an implied private right of action under Title IX, the Court expressed concern that the termination of federal funding "[might] not provide an appropriate means of accomplishing the second purpose," the protection of individuals. ${ }^{107}$ Thereafter, the Supreme Court reaffirmed Congress's commitment to the protection of individuals in Franklin, where the Court rejected the argument that Title IX remedies should be limited to backpay and prospective relief. ${ }^{108}$ The Court explained that such remedies were "inadequate" and would leave the plaintiff "remediless." ${ }^{109}$ Here, the removal of punitive damages in Title IX cases has the same effect. Thus, the application of Barnes to Title IX claims wrongly thwarts one of Congress's two Title IX objectives: the protection of individuals.

\section{PART IV: CONCLUSION}

There is more at stake in the failure of Title IX enforcement than the opportunity to compete in a softball game, a tennis match, or a swimming meet. What is lost is the self-worth of adolescent girls- "There isn't anything for us," one Western Pennsylvania high school senior explained to the Pittsburgh Tribune-Review, "There could be a whole lot more. There could be softball. There could be track for us. But there's none of that; it's all for the boys. I'm graduating, and time has run out for me." ${ }^{110}$ Another senior had an even more disheartening comment:

106. Cannon v. Univ. of Chi., 441 U.S. 677, 704 (1979).

107. Id. at 705 .

108. Franklin v. Gwinnett County Pub. Sch., 503 U.S. 60, 76 (1992).

109. $I d$.

110. Prine, supra note 2. 
In sports, everybody thinks that boys are all better than girls. It's not true. They run, they lift, they work hard-but so do we. We work just as hard and spend just as much time in the gym and on the field, no matter how bad our field or our equipment may be.... We want to work as hard as they do. We're tired of always being secondstringers. It's frustrating. We deserve everything the boys do. ${ }^{11}$

By encouraging adolescent girls to see themselves as "second-stringers" on the field, we encourage them to see themselves as second-stringers in their professional and social lives as well. In failing to ensure Title IX compliance, we send a terrible and unjustifiable message to thousands of girls across the country: "Sorry ladies, boys come first."

Ensuring the availability of punitive damages under Title IX is one way to improve the lack of adequate Title IX enforcement. Punitive damages will both encourage schools to voluntarily comply with Title IX, and encourage female athletes to overcome adversity to expose discrimination. Unfortunately, as Parts II and III of this Note demonstrate, the obstacles to punitive damages under Title IX are formidable. Over the past twenty years, virtually no court has upheld punitive damage awards against secondary schools for Title IX violations. As a result, the most effective way to improve the enforcement of Title IX would be congressional legislation affirming the availability of punitive damages in Title IX lawsuits. However, should this not occur, courts still have room to act, as the law remains unsettled. The Newport rule barring punitive damages against municipalities under $\S 1983$ claims does not automatically apply to Title IX, and the policy considerations of the Newport test counsel against such an application. Likewise, only one circuit court has extended the Barnes punitive damages bar to Title IX, and it did so in a cursory and unpublished opinion. Congressional intent would be better served by courts recognizing the availability of punitive damages.

Thus, while congressional action would be helpful, it is not required for courts to uphold punitive damage awards in Title IX claims. Courts still have the opportunity to improve Title IX enforcement and remedy the unequal treatment of female student athletes. Courts can, and should, give girls a fighting chance. 